\title{
Corruption and SME growth: the roles of institutional networking and financial slack
}

\author{
Samuel Adomako ${ }^{\star}$ (D), Mujtaba Ahsan², Joseph Amankwah-Amoah ${ }^{3}$, Albert Danso ${ }^{4}$, \\ Kwabena Kesse ${ }^{5}$ and Kwabena Frimpong 6 \\ ${ }^{1}$ School of Management, University of Bradford, Bradford, UK, ${ }^{2}$ Fowler School of Business, San Diego State University, \\ San Diego, CA, USA, ${ }^{3}$ Kent Business School, University of Kent, Canterbury, Kent, UK, ${ }^{4}$ Leicester Castle Business School, \\ De Montfort University, Leicester, UK, ${ }^{5}$ Beacom School of Business, University of South Dakota, Vermillion, SD, USA and \\ ${ }^{6}$ KFUPM Business School, King Fahd University of Petroleum and Minerals, Dhahran, Saudi Arabia \\ *Corresponding author. Email: S.Adomako@bradford.ac.uk
}

(Received 12 January 2020; revised 1 January 2021; accepted 1 January 2021; first published online 10 February 2021)

\begin{abstract}
In this study, we investigate the mediating effect of institutional networking on the relationship between perceived corruption and the growth of small and medium-sized enterprises (SMEs). We also examine the moderating impact of financial slack on the relationship between perceived corruption and institutional networking. We test our moderated mediation model using data from 212 SMEs operating in Ghana. The findings from the study show that perceived corruption is positively related to institutional networking and this relationship is amplified when levels of financial slack are greater. The findings also show that institutional networking positively mediates the relationship between perceived corruption and SME growth. Theoretical and practical implications are discussed.
\end{abstract}

Key words: Ghana; growth; perceived corruption; SMEs

\section{Introduction}

Developing nations are often fraught with corruption, which affects both business and society (Barkemeyer et al., 2018; Bryant and Javalgi, 2016; Olken and Pande, 2012). Indeed, scholars argue that corruption adversely impacts economic development and shifts the benefits from society to corrupt individuals (Alm et al., 2016; Gründler and Potrafke, 2019; Mo, 2001; Murphy et al., 1991). As entrepreneurship plays a key role in economic development and wealth creation (Baumol, 1990), this issue has received growing attention in the entrepreneurship literature. Researchers have predominantly utilised macro-level data to examine the relationship between corruption and entrepreneurial activities (Anokhin and Schulze, 2009; Dreher and Gassebner, 2013; Mohamadi et al., 2017; Wellalage et al., 2019a, 2019b). Interestingly, these studies present mixed findings. Although some scholars have emphasised that corruption has a 'sanding' (negative) impact on entrepreneurial activities (De Rosa et al., 2015; Dutta and Sobel, 2016), others have highlighted its 'greasing' (enabling) effect on entrepreneurial activities (Dreher and Gassebner, 2013; Fisman and Svensson, 2007).

Furthermore, recent findings indicate that the effect of corruption varies based on the type of corruption as well as on the types of entrepreneurs. In their study on private manufacturing small and medium-sized enterprises (SMEs) in Vietnam, $\mathrm{Vu}$ et al. (2018) find that various types of corruption (bribe) have different effects on firms' financial performance. In particular, they find that some types of bribe do not affect firm performance, whereas bribes to obtain government contracts and licences harm firm performance. In contrast, firms that pay bribes for public services may have a higher

(C) Millennium Economics Ltd 2021. This is an Open Access article, distributed under the terms of the Creative Commons Attribution licence (http://creativecommons.org/licenses/by/4.0/), which permits unrestricted re-use, distribution, and reproduction in any medium, provided the original work is properly cited. 
performance compared to firms that do not. Similarly, scholars have recently examined whether the sanding and greasing effects of corruption vary according to the type of entrepreneur (Goel and Saunoris, 2019). They find that the sanding effect of corruption varies across types of entrepreneurs ${ }^{1}$ and it switches to greasing effect for nascent entrepreneurs.

Although in developed countries entrepreneurs can rely on various institutions when starting and operating their businesses, entrepreneurs operating in developing countries often need to take actions to manage the uncertainties associated with operating in such weak institutional environments (Ahsan et al., 2020; Hunt, 2015; McMullen and Shepherd, 2006). This is because weak institutional environments are characterised by underdevelopment of market-supporting formal infrastructures such as regulatory and legal systems (Khanna and Palepu, 1997; Puffer et al., 2010). Interestingly, Vorley and Williams (2016) argue that entrepreneurs can adopt two strategies when operating in environments with high levels of corruption: avoiding the attention of government officials and engaging in corruption. Although this research provides useful insights into the strategies that entrepreneurs could adopt, we still have a limited understanding of the agency entrepreneurs display to manage the challenges of operating in environments fraught with corruption.

In particular, we lack an understanding of the actions the key decision-makers of SMEs (e.g. owners and CEOs) operating in such an environment take to ensure the survival and success of their firms. In contrast to larger firms that have the significant financial resources and work with lobbyists to create conducive environments for their businesses (Doh et al., 2003; Luiz and Stewart, 2014), SMEs have limited resources and therefore need to be strategic in how they utilise these resources (Lee et al., 1999; Terziovski, 2010). Furthermore, in SMEs, the key decision-makers play an influential role, and they are directly involved in the actions that are taken to buffer their firms against adverse impacts (Child and Hsieh, 2014; Ling et al., 2008; Sawyerr et al., 2003). Consequently, the entrepreneurial agency they demonstrate could very well be the difference between the success and failure of their firms.

A significant amount of literature has emphasised that entrepreneurial networking is an important action that entrepreneurs can engage in to acquire critical resources and enhance the performance of their firms (for reviews see Hoang and Antoncic, 2003; Hoang and Yi, 2015). Networks enable entrepreneurs to acquire critical resources, manage uncertainties and position their venture for success (Hallen and Eisenhardt, 2012; Phillips et al., 2013). Recent findings indicate that entrepreneurs develop networks to mitigate the uncertainties they perceive in starting and operating their ventures (Engel et al., 2017; Magnani and Zucchella, 2019; Zheng et al., 2020). Given that corruption and associated uncertainties can impact the ability of entrepreneurs to capture the value and the magnitude of the value captured (Baker et al., 2005; Baumol, 1990), networking can play a critical role in ensuring that entrepreneurs can create and capture appropriate value. Although the dominant focus of entrepreneurial networking literature has been on personal (e.g. family and friends) and business ties (suppliers and advisors), a small number of studies have examined institutional networks ${ }^{2}$ that entrepreneurs develop with government officials to attain critical resources and special privileges (Adomako et al., 2020; Ge et al., 2019; Wang et al., 2018; Zhang et al., 2016; Zhou, 2013).

Utilising insights from this literature, we argue that entrepreneurs who perceive the prevalence of corruption in the environments in which they operate will develop ties with government officials (e.g. ministers and regulators) who can help them protect their investments and attain success. However, developing such institutional networks would require financial resources beyond what is necessary to smoothly operate the firm. One operationalisation that has often been used in the strategic management literature to measure the financial resources a firm has to engage in strategic activities is financial

\footnotetext{
${ }^{1}$ (1) Individuals who are in the process of setting up a business (nascent entrepreneurs); (2) individuals who own or manage a business that has been operational for more than 3 months but less than 42 months (new business owners); (3) individuals who own or manage a business that has been operational for more than 42 months (established entrepreneurs).

${ }^{2}$ Institutional networks are relationships that firms develop with public entities (Kim and Lui, 2015). Some scholars have also referred to these ties as 'political connections' (Wang et al., 2018). We refer to these ties as 'institutional networks' as the relationships that firms in our sample develop are not solely with politicians (e.g. members of parliament and regional ministers), but also with individuals working in various state institutions such as banks, taxation and regulatory entities.
} 
slack (Ang and Straub, 1998; Cheng and Kesner, 1997; Voss et al., 2008). We, therefore, argue that financial slack, which reflects financial resources the firm possesses above what it needs for its current operations (Kiss et al., 2018; Kraatz and Zajac, 2001), will enable the effective development of these ties. Financial slack allows a firm to engage in strategic actions without putting itself at high risk by increasing debt and financially overextending. Financial slack is especially valuable for SMEs in countries where corruption is prevalent as it is challenging to access credit in such environments (Wellalage et al., 2019a).

In our study, using a sample of 212 Ghanaian SMEs from the manufacturing and service sectors, we examine the mediating effects of institutional networking on the relationship between perceived corruption and firm growth. Furthermore, we examine the moderating effect of financial slack on the relationship between perceived corruption and institutional networking. The institutional environment in less developed countries differs significantly from that of more developed countries (Adomako, et al., 2018; Fainshmidt et al., 2018). Entrepreneurs operating in such environments have to actively navigate the business environments and manage uncertainties. As we have already mentioned, entrepreneurs who perceive corruption to be prevalent are likely to be more active in developing ties with individuals in government institutions (institutional networking). Such ties could buffer firms from the unpredictability of the business environment as well as give them privileged access to resources, which would likely enable them to attain higher performance (growth).

This study makes three main contributions. First, we contribute to the emerging literature examining the relationship between corruption and firm performance. Although the extant literature provides interesting insights, the findings from these studies are mixed and the mechanism through which corruption affects firm performance is unclear. Second, we examine the mediating effects of institutional networking to shed light on the mechanism through which corruption affects the performance of SMEs. Entrepreneurs who perceive corruption in the environments in which they operate, actively engage in actions to protect their investments. Such entrepreneurs develop relationships with officials in government, regulatory and financial institutions to mitigate the uncertainties, including opportunistic behaviours by bribee, which enhances firm growth. Third, we find that financial slack moderates the perceived corruption-institutional networking relationship. Financial slack allows entrepreneurs to initiate and develop relationships with institutional ties (e.g. government and officials), without putting the firm at risk by financially overextending.

Our paper proceeds as follows. In the next section, we develop a theoretical model focusing on the relationships among perceived corruption, institutional networking and firm growth including the moderating effects of financial slack. We follow this with a section describing the research methodology and key findings. The final section outlines both the theoretical and practical implications of this study.

\section{Theory and hypotheses development}

\subsection{Institutions and corruption}

Institutions affect the allocation of entrepreneurial resources in a country (Baumol, 1990; Boudreaux, 2014; Grossman and Kim, 1995), and correspondingly entrepreneurs shape the institutions in which they operate by actively responding to the institutional environment (Henrekson and Sanandaji, 2011). Weak institutional environments provide a fertile ground for corruption to flourish and this necessitates action from entrepreneurs to manage associated uncertainties (McMullen and Shepherd, 2006; Tonoyan et al., 2010). In the context of developing economies, there is disorganised corruption, where bureaucrats (e.g. government officials, civil servants and bank managers) collect bribes to perform their basic government functions (Shleifer and Vishny, 1993, Vu et al., 2018). This presents challenges to entrepreneurs in operating their business. Consequently, even tasks that are considered as normal activities in developed institutional environments, such as attaining bank loans or business permits, can be challenging in environments fraught with corruption. The prevalence of corruption that the entrepreneurs perceive varies based on the type of industry in which they operate and the number of times they have to interact with bureaucrats. Some industries such as the oil and gas sector 
in Ghana (Ablo, 2019) are highly regulated. When such regulatory requirements are coupled with weak institutions, entrepreneurs are more likely to encounter corruption as the institutions responsible for enforcing the laws to dissuade civil servants and political elites from engaging in corrupt behaviours are either unwilling to enforce them or incapable of doing so. Consequently, small firms will likely need more resources to attain the approvals needed to operate a business in this sector compared to, say, a small firm manufacturing furniture. ${ }^{3}$

Researchers argue that corruption increases the agency and transaction costs for entrepreneurs (Anokhin and Schulze, 2009; Avnimelech and Zelekha, 2015; Jimenez et al., 2017). As corruption entails government officials acting based on their self-interest, this has the potential to distort the functioning of markets and market competition (Svensson, 2005). However, weak institutional environments, due to their bureaucracy and lack of supporting institutions, can hinder the entrepreneurial process and make corruption an attractive option. Under such conditions, corruption can grease the entrepreneurial process to prevent inordinate delays in procuring necessary approvals and/or resources (Bardhan, 1997; Dreher and Gassebner, 2013). Entrepreneurs could receive special and beneficial treatment by engaging in corruption, such as bank loans, permit approvals, direct contracts and regulation favours (Acquaah, 2007; Dheer, 2017; Wellalage et al., 2019a, 2019b). Furthermore, entrepreneurs in developing countries have limited alternate opportunities to earn income (Ahsan et al., 2020), which may compel them to engage in bribery and other forms of corruption (e.g. circumventing tax and business laws) to succeed. Consequently, entrepreneurs who perceive the prevalence of corruption in their environments may come to believe that engaging in corruption is the way to do business and attain success. Researchers suggest that individuals' perception of how prevalent corruption is in their environment can lead them to engage in similar practices and justify their actions (Gorsira et al., 2018; Rose-Ackerman, 2001; Tonoyan et al., 2010). The cost of not engaging in corruption could be high for individuals who choose not to participate in this practice, and they will likely be ignored in favour of those who do - that is, pay to play (Della Porta and Vannucci, 1999). Indeed, Getz and Volkema (2001) argue that firms will engage in bribery if they perceive it to be prevalent, as reluctance to do so can significantly harm their company.

Although bribing could grease the entrepreneurial process and enable firms to be successful, engaging in bribery in a weak institutional environment is not without risk. Anokhin and Schulze (2009) note that the bureaucrats whom the entrepreneur bribes may not perform the service despite getting paid for it and they may demand additional payments without fear of repercussion as the entrepreneur will have few, if any, options other than relying on them in such environments. To prevent such opportunistic behaviour, the entrepreneur and/or the key decision-makers will likely attempt to develop good relationships with various institutional actors. By developing good relationships with institutional ties such as government officials, bank managers, etc., they can minimise agency and transaction costs. In other words, good relationships with institutional ties could increase credit availability, shorten the administrative approval process, provide access to privileged information, and, more importantly, mitigate opportunistic behaviours. Indeed, D'Aveni and Kesner (1993) emphasise that such elite connections enable firms to manipulate the external environment and sway other actors to behave in a manner that is beneficial to the firm.

Moreover, institutional ties can potentially enhance value creation and value capture, which in turn bolster firm performance (Feng et al., 2015; Lepak et al., 2007; Semrau and Sigmund, 2012; Sun et al., 2012). However, owners/CEOs of SMEs need to have sufficient financial resources to engage institutional ties and develop good relationships with them, as such connections are often developed by socialising in the same circles (Barton, 1985; Davis et al., 2003; Maclean et al., 2010, 2017). The challenge of accessing credit in environments where corruption is prevalent (Wellalage et al., 2019a) makes

\footnotetext{
${ }^{3}$ This is consistent with the notion of 'local bribery environment' that argues bribery is industry- and region-specific (Fisman and Svensson, 2007; Hanousek and Kochanova, 2016). This suggests that firms operating in certain industries/ regions would need to rely more on institutional ties to attain resources and/or approvals, and therefore might perceive a higher prevalence of corruption.
} 
financial slack even more valuable. Next, we explain the hypothesised relationships among the variables in the model.

\subsection{Perceived corruption and institutional networking}

Institutional networks may be broadly explained as the ties, contacts or relationships that the entrepreneurs develop with actors in public organisations for the purpose of obtaining privileged services (Acquaah, 2007; Luo et al., 2008). As discussed in the previous section, entrepreneurs who perceive corruption in their industry environment are likely to engage in corruption to protect their investments and maintain their firms' competitiveness (Getz and Volkema, 2001). This is more likely to be true in a context where corruption is prevalent and the cost of doing business is high (Goel and Saunoris, 2019; Mohamadi et al., 2017). Usually, poorly defined laws and unclear regulations increase the cost of doing business and this could motivate entrepreneurs to bribe bureaucrats to circumvent the burdensome process and sustain their firms' competitiveness. Although corruption could facilitate the entrepreneurial process, especially in countries with weak institutional environments (De Rosa et al., 2015; Dreher and Gassebner, 2013), such environments also promote opportunistic behaviours that the firms must safeguard against (Luo, 2005; Tonoyan et al., 2010).

Entrepreneurs engaging in bribery do not have the recourse of approaching the law in the event of opportunistic behaviour by the bribee nor can they draw up formal contracts to ensure that the services are rendered as per their payment agreements (Tonoyan et al., 2010). Researchers argue that entrepreneurs can reduce the uncertainties they experience by taking action (McMullen and Shepherd, 2006), including designing an alternate mechanism to mitigate opportunism (Rose-Ackerman, 1999). Given these challenges, entrepreneurs seek to establish relationships with institutional ties to gain privileged access to resources as well as create a favourable environment for the firms (Acquaah, 2007; Dheer, 2017). In such environments, 'who you know' matters considerably as the 'right' connections can open access to resources and eliminate obstacles that firms typically encounter (D'Aveni and Kesner, 1993; Guseva, 2007). More importantly, such ties can mitigate opportunistic behaviour and reduce uncertainties (Adomako et al., 2020) as well as ensure that the corrupt transactions are performed as agreed (Lambsdorff, 2005). These arguments lead us to suggest the following hypothesis:

H1: Perceived corruption is positively related to institutional networking.

\subsection{Perceived corruption, networking and firm performance}

A critical review of the literature indicates mixed findings regarding the effects of corruption on firm outcomes. Although some studies find corruption to be detrimental (De Rosa et al., 2015; Fisman and Svensson, 2007), others demonstrate that corruption is ideal for performance (Hanousek, and Kochanova, 2016; Vial and Hanoteau, 2010). These seemingly contrasting outcomes may be due to the fact that this relationship may be more nuanced and contingent on the agency of the entrepreneurs. We contend that institutional networks serve as a lynchpin in ensuring that entrepreneurs can capture the value when they engage in corruption. Institutional ties provide three advantages to firms in weak institutional environments (Acquaah, 2007; Tonoyan et al., 2010; Wellalage et al., 2019a). First, institutional networks can provide valuable resources that are critical for firms' growth, especially in environments with weak institutions and less transparent bureaucracies. Second, institutional networks reduce the length of the approval process required in the consumption of vital services. Thus, entrepreneurs who leverage on this could enhance their firms' speed to market. Finally, and more importantly, these ties ensure that the bribes that entrepreneurs pay to 'grease the wheel' are not misappropriated by opportunistic actors. This is so because entrepreneurs who can establish good relationships with institutional ties can create a trust-based network and ensure that the other actors (that is, bribees) act in a manner that is favourable to the firm (D'Aveni and Kesner, 1993). Indeed, strong bonding with ties can create an environment for corruption to flourish (Tanzi, 
1998). Findings from prior studies indicate that good relationships with network ties enhance trust, which positively affects firms' performance (Brüderl and Preisendörfer, 1998; Lin and Lin, 2016; Mackinnon et al., 2004). Thus, we state:

H2: Institutional network mediates the effect of perceived corruption on SME growth.

\subsection{The moderating role of financial slack}

Financial slack is the level of liquid assets (e.g. cash on hand) available for immediate deployment by a firm (Kiss et al., 2018; Kraatz and Zajac, 2001). Voss et al. (2008) suggest that financial slack is valuable, but generic and less rare compared to other types of resource slacks. Given that SMEs, especially those in developing countries, are resource-constrained and are often confronted by challenges, such as limited access to credit (Terziovski, 2010; Wellalage et al., 2019a), financial slack can be considered a rare and valuable resource. This is because the possession of financial slack by SMEs enables them to engage in strategic organisational activities (Ang and Straub, 1998; Cheng and Kesner, 1997; Voss et al., 2008). SMEs are not restricted in the manner in which they can deploy financial slack and they can apply it to any activity they deem as strategically important for firm survival and success. That is, they can use their excess financial resources to engage in networking activities such as becoming members of exclusive sporting clubs and cultural organisations which would enable them to socialise and develop relationships with elite ties (D'Aveni and Kesner, 1993). This could give SMEs privileged access to resources and other benefits. Given the opportunity cost of not engaging in corruption in an environment where it is prevalent, along with the risk of losing competitiveness (Getz and Volkema, 2001; Tonoyan et al., 2010), entrepreneurs might more likely be motivated to establish relationships with elite ties (i.e. connections with important institutional actors) to influence the action of other actors (D'Aveni and Kesner, 1993) as well as mitigate opportunistic behaviours (Lambsdorff, 2005).

In other words, although many SMEs may be motivated to engage in corruption in environments with high corruption, only those who have financial slack are able to engage in networking activities necessary to connect with elite ties. Although SMEs that lack financial slack could attempt to avail capital from other sources of finances such as loans and utilise debt capital to establish relationships with institutional ties, the likelihood of attaining such loans in weak institutional environments is slim (Wellalage et al., 2019a). As a result, firms that do not have financial slack may be locked out from accessing opportunities that privileged networks may beget (Della Porta and Vannucci, 1999; Getz and Volkema, 2001). Thus, the 'financial buffer' stemming from the possession of financial slack reduces the risk to the SMEs as it protects them from the uncertain outcomes of these strategic activities (Ang and Straub, 1998; Cheng and Kesner, 1997; Voss et al., 2008). It gives SMEs the flexibility to develop good relationships with different institutional ties that could help them protect their investments and attain future success. The foregoing reasoning leads us to suggest a more positive effect of perceived corruption on institutional networking when financial slack is higher. Accordingly, we hypothesise that:

H3: Availability of financial slack amplifies the effect of perceived corruption on institutional networking.

\section{Research method}

\subsection{Research setting: Ghana}

In testing our hypotheses, we used data obtained from SMEs operating in Ghana. We focused on Ghana because its environmental context was considered appropriate. First, many owners/CEOs of SMEs in the country have ties with politicians and bureaucrats (Acquaah, 2007). Second, corruption is pervasive, making the country rank 80th out of 180 countries according to Transparency International's 2017 Corruption Perception Index (CPI) (Transparency International, 2017). This 
high prevalence of corruption in Ghana presents unique challenges for entrepreneurs (Joseph, 2019; Moo and Eyiah, 2019). This makes this context a suitable environment in which to test the proposed hypotheses regarding the nexus between corruption and firm performance. Third, Ghana has struggled to be competitive on the global stage in terms of developing vibrant markets. Moreover, the institutional environment in Ghana presents an interesting context for the study because it differs significantly from those in more developed countries (Amankwah-Amoah, 2016; Fainshmidt et al., 2018). Overall, Ghana ranks 111th out of 137 countries, according to the 2017-2018 Global Competitiveness Report (GCR). Thus, Ghana offers a typical developing country's perspective to test our conceptual model.

\subsection{Sample and data collection}

The sampling frame for this study was derived from the Ghana Revenue Authority (GRA) databases. We contacted, by telephone, 800 firms to ask them for their participation in the study. Our sample met the following criteria: (1) independent, i.e. not part of any company group; (2) owned and operated by an entrepreneur or a team of entrepreneurs; (3) manufacturer of goods or a service provider; (4) employing a maximum of 250 full-time employees; the criteria we used to classify the firms in our sample as SMEs and (5) each respondent had to have direct executive authority for their respective firm.

The survey questions were in a randomised order to counter bias effects. To attenuate the threat of common method bias (Podsakoff et al., 2003), we collected the data in two waves using a handdelivery survey strategy. First, we approached the entrepreneurs with questionnaires in person to collect data on the independent variables (perceived corruption, institutional networking and the control variables). After two rounds of reminders, we received a total of 272 responses, representing a $34 \%$ response rate. We detected that 17 of the questionnaires were incomplete. These were therefore discarded, leaving 255 complete responses (approximately 32\% response rate).

Second, we collected data from the finance managers of the firms to measure financial slack and firm growth. After making two reminders by telephone, we received a total of 228 responses. We observed that 16 of the finance managers were also the founders/entrepreneurs of the firms. Hence, we discarded those 16 questionnaires to minimise common method bias.

Overall, 212 complete responses across Time 1 and Time 2 were used for the analysis. This represents a $26.5 \%$ response rate (i.e. [212/800] $\times 100)$. On average, the firms employ 22 full-time employees and have been in business for 8 years since their inception. The firms operate in multiple industries, including agro-processing (40\%), food and beverage processing (10\%), textile and garment manufacturing (5\%), security services $(24 \%)$ and financial services $(21 \%)$. Thus, the majority of the sampled firms operate in the manufacturing industry (55\%) whereas a few provide services $(45 \%)$.

\subsection{Measure of constructs}

In line with the literature, a seven-point multi-item scale was used to measure the constructs.

We measured perceived corruption $(\alpha=0.93)$ using a six-item scale from previous studies (Collins et al., 2016; Doh et al., 2003; Uhlenbruck et al., 2006). This scale taps the extent to which entrepreneurs perceive corruption as pervasive within their politico-economic institutional environment.

Institutional networking $(\alpha=0.88)$ was assessed using a four-item scale from Acquaah (2007). This scale measures network relationships with government officials and politicians.

Financial slack: The approach used by Voss et al. (2008) was utilised to assess the firms' cash reserves at the end of the 2018 financial year to measure financial slack. Firm size was controlled by dividing cash reserves by the venture's total expenses in the 2018 financial year.

To measure firm growth, the dependent variable, the finance managers were asked in the survey to record the level of employment growth in their firms 3 years before the data collection. Using these data and following previous studies (Brouwer et al., 1993; Robson and Obeng, 2008), we included an annualised growth rate for employment in the ordinary least squares regression.

Control variables: Several control variables such as firm size, firm age, industry type and founder age/education were used because they were considered important factors which might influence the 
research model. Firm size was measured with the number of full-time employees, whereas firm age was captured as the number of years the business has operated since its first sales. Industry was measured with a dummy variable, with ' 0 ' indicating manufacturing industry and ' 1 ' indicating otherwise. Finally, we controlled for founder age and education (' 1 ' = 'High School', '2' = 'Higher National Diploma', '3' = 'Bachelor's Degree', '4' = 'Master's Degree' and '5' = 'Doctoral Degree').

\subsection{Tests for potential biases}

We performed two major tests to check for potential biases. First, we checked the possibility of nonresponse bias by comparing respondents and non-respondents in terms of firm age, size, industry, founder age and education using Pearson's chi-square test for discreet variables (Greenwood and Nikulin, 1996). We found no significant differences between the two groups. Thus, we concluded that nonresponse bias did not influence our dataset (Armstrong and Overton, 1977; Rogelberg and Stanton, 2007). Second, we followed the procedure suggested by Lindell and Whitney (2001) to test for potential common method variance. Accordingly, a marker test was used to assess the correlations between the marker variable and the main constructs. The item 'I enjoy coming up with new ideas for products' was used as a marker variable, which is considered a measure of intrinsic interest in entrepreneurship, a variable which is theoretically unrelated to firm growth. The results indicate a non-significant correlation ranging from -0.01 to 0.03 . The results of partial correlations were also significant, even after we had discarded the effect of common method bias. A 95\% sensitivity analysis was used to verify this conclusion. Overall, we believe that issues related to common method bias are negligible in this study.

\subsection{Validity and reliability assessment}

The reliability and validity of the constructs were subjected to exploratory factor analysis. A confirmatory factor analysis (CFA) was performed to refine the items using LISREL 9.30 and covariance matrices as input data. The results of the CFA provide adequate fit for the data: $\chi^{2}$ (degree of freedom) $=$ 920.44 (590); $p<0.00$; RMSEA $=0.06$; NNFI $=0.95$; $\mathrm{CFI}=0.97$ and $(\mathrm{SRMR})=0.07$. Also, the factor loadings for each construct were significant at $p<0.01$. This indicates the convergent validity of the measures (Bagozzi and Yi, 1988).

The reliability of the constructs was assessed using composite reliability, average variance extracted (AVE), and the highest shared variance (HSV) of the constructs. All the indices were greater than the recommended threshold value of 0.70 (Bagozzi and Yi, 1988). Utilising Fornell and Larcker's (1981) approach, the discriminant validity of each construct was assessed by investigating whether the AVE for each construct was greater than the shared variances of each pair of constructs. Discriminant validity was determined as the AVE for each construct was larger than the HSV between each pair of constructs.

\section{Results}

The descriptive statistics for the model variables are presented in Table 1. Before conducting the main regression analyses, the continuous variables were mean-centred to alleviate the potential multicollinearity concerns associated with moderating hypotheses (Aiken et al., 1991). The results show that the highest variance inflation factor (VIF) is 4.19 , which is well below the recommended threshold value of 10 (Neter et al., 1990). We also checked the data for potential violations of normality assumptions and outliers. The results suggested no significant violations. Thus, the data were deemed suitable for the regression analysis. The hierarchical regression was then used to test the hypotheses. Table 2 presents the regression results.

In models $1-4$, the dependent variable is institutional networking. Model 1 includes all the control variables. In model 2, we test the effect of perceived corruption on institutional networking. The results showed that perceived corruption has a significant positive influence on institutional networking $(\beta=0.25, p<0.01)$, thus supporting hypothesis 1 . When financial slack was added in model 3 , the 
Table 1. Descriptive statistics and correlations

\begin{tabular}{|c|c|c|c|c|c|c|c|c|c|c|c|}
\hline & Variables & Mean & S.D. & 1 & 2 & 3 & 4 & 5 & 6 & 7 & 8 \\
\hline 1 & Firm size (employees) & 22.40 & 12.35 & & & & & & & & \\
\hline 2 & Firm age (years) & 8.63 & 6.87 & -0.04 & & & & & & & \\
\hline 3 & Founders' age & 52.55 & 28.81 & -0.02 & 0.00 & & & & & & \\
\hline 4 & Industry dummy & 0.55 & 0.50 & 0.13 & $0.26^{\star \star}$ & 0.02 & & & & & \\
\hline 5 & Education & 2.98 & 1.15 & 0.12 & 0.02 & 0.01 & 0.00 & & & & \\
\hline 6 & Financial slack ${ }^{a}$ & 17.85 & 42.20 & $0.19^{\star \star}$ & 0.09 & 0.00 & $0.23^{\star \star}$ & 0.08 & & & \\
\hline 7 & Institutional networking & 4.60 & 0.99 & $0.29^{\star \star}$ & $0.14^{\star}$ & 0.08 & $0.14^{\star}$ & $0.13^{*}$ & $0.17^{\star}$ & & \\
\hline 8 & Perceived corruption & 4.93 & 0.70 & $0.21^{\star \star}$ & -0.03 & 0.09 & $0.17^{\star}$ & 0.09 & $0.25^{\star \star}$ & $0.33^{\star \star}$ & \\
\hline 9 & Employment growth rate & 7.35 & 12.84 & 0.08 & -0.04 & 0.03 & $0.16^{\star}$ & $0.24^{\star \star}$ & $0.20^{\star *}$ & $0.26^{\star \star}$ & $0.22^{\star \star}$ \\
\hline
\end{tabular}

S.D., standard deviation.

$N=212$.

aThe mean value for this construct can be interpreted as a percentage.

${ }^{\star} p<0.05,{ }^{* *} p<0.01$ (2-tailed test). 
Table 2. Findings of the moderated mediation regression model

\begin{tabular}{|c|c|c|c|c|c|c|c|c|}
\hline & \multicolumn{4}{|c|}{ Models 1-4: institutional networking } & \multicolumn{4}{|c|}{ Models 5-8: firm growth } \\
\hline & Model 1 & Model 2 & Model 3 & Model 4 & Model 5 & Model 6 & Model 7 & Model 8 \\
\hline \multicolumn{9}{|l|}{ Control variables } \\
\hline Firm size (employees) & $0.18^{\star \star \star}$ & $0.18^{\star \star \star}$ & $0.19^{\star \star \star}$ & $0.18^{\star \star \star}$ & $0.09^{*}$ & $0.10^{*}$ & $0.10^{*}$ & $0.11^{\star}$ \\
\hline Firm age & $0.09^{\star}$ & $0.10^{*}$ & $0.11^{\star}$ & $0.11^{\star}$ & $-0.10^{\star}$ & $-0.10^{*}$ & $-0.10^{*}$ & $-0.11^{*}$ \\
\hline Founders' age & 0.04 & 0.05 & 0.05 & 0.05 & 0.04 & 0.04 & 0.05 & 0.05 \\
\hline Education & 0.06 & 0.06 & 0.06 & $0.07^{\star}$ & $0.09^{\star}$ & $0.09^{*}$ & $0.09^{*}$ & $0.10^{*}$ \\
\hline Industry dummy & $0.09^{*}$ & $0.09^{*}$ & $0.10^{\star}$ & $0.11^{*}$ & $0.14^{\star \star}$ & $0.14^{\star \star}$ & $0.14^{\star *}$ & $0.14^{\star \star}$ \\
\hline \multicolumn{9}{|l|}{ Independent variable } \\
\hline Perceived corruption (PC) & & $0.25^{\star \star \star}$ & $0.24^{\star \star \star}$ & $0.24^{\star \star \star}$ & & $0.19^{\star \star \star}$ & & 0.02 \\
\hline \multicolumn{9}{|l|}{ Moderator } \\
\hline Financial slack (FS) & & & $0.18^{\star \star \star}$ & $0.18^{\star \star \star}$ & $0.22^{\star \star \star}$ & $0.22^{\star \star \star}$ & $0.18^{\star \star \star}$ & $0.18^{\star \star \star}$ \\
\hline \multicolumn{9}{|l|}{ Interaction } \\
\hline $\mathrm{PC} \times \mathrm{FS}$ & & & & $0.46^{\star \star \star}$ & & & & \\
\hline \multicolumn{9}{|l|}{ Mediator } \\
\hline Institutional networking & & & & & & & $0.22^{\star \star \star}$ & $0.22^{\star \star *}$ \\
\hline \multicolumn{9}{|l|}{ Model fit statistics } \\
\hline$F$ & 1.50 & $3.93^{\star * *}$ & $5.71^{\star \star \star}$ & $7.28^{\star \star \star}$ & $2.66^{\star *}$ & $4.28^{\star \star \star}$ & $5.95^{\star \star \star}$ & $6.77^{\star \star \star}$ \\
\hline$R^{2}$ & 0.14 & 0.17 & 0.23 & 0.31 & 0.15 & 0.19 & 0.25 & 0.27 \\
\hline$\Delta R^{2}$ & - & 0.03 & 0.06 & 0.08 & - & 0.04 & 0.06 & 0.02 \\
\hline Largest VIF & 2.44 & 4.19 & 2.19 & 1.31 & 2.01 & 1.29 & 2.53 & 2.54 \\
\hline
\end{tabular}

$N=212$.

${ }^{* \star *} p<0.01,{ }^{* \star} p<0.05,{ }^{*} p<0.10$. Standardised coefficients are shown. 


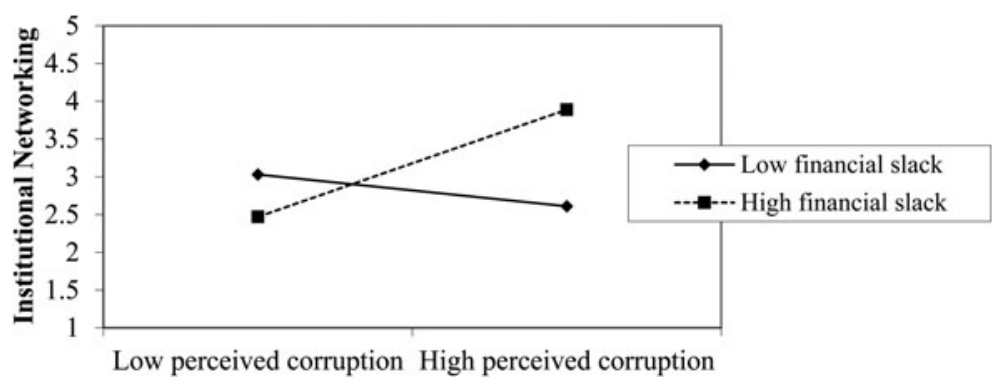

Figure 1. Interaction effect of perceived corruption with financial slack on institutional networking.

effect of perceived corruption on institutional networking remained significant $(\beta=0.24, p<0.01)$. In model 4 , we examine the moderating effect of financial slack on the relationship between perceived corruption and institutional networking. The results suggest that the interaction term is positive and significant $(\beta=0.46, p<0.01)$, indicating that financial slack positively moderates the relationship between perceived corruption and institutional networking. To establish the direction of the two-way interaction, we followed the procedure advanced by Cohen et al. (2003) to investigate the moderating hypothesis. The graphical representation in Figure 1 shows a stronger positive relationship between perceived corruption and institutional networking when financial slack is high (versus low financial slack). Simple slope analysis also shows that the effect of perceived corruption on institutional networking is significant when financial slack is high $(t=2.99, p<0.01)$ but not when it is low $(t=$ $0.45, n s)$. This indicates support for hypothesis 3 .

The dependent variable in models 5-8 is firm growth. The results in these models allow us to test the mediating hypothesis (H2). The mediating hypothesis was tested using the approach suggested by Baron and Kenny (1986) and refined by Zhao et al. (2010). According to this approach, mediation relationships must meet three conditions. First, the independent variable and the mediator should be related significantly. The result in model 2 shows that the association between perceived corruption and institutional networking is positive and significant $(\beta=0.25, p<0.01)$. Second, the mediating variable and the dependent variable should be significantly related to each other. The result in model 7 shows that institutional networking and firm growth are significantly related to each other $(\beta=$ $0.19, p<0.01)$. Third, the effect of the independent variable on the dependent variable must not be significant when the mediating variable is added to the regression equation. In model 8 , when perceived corruption was included in the regression equation, institutional networking had a positive influence on firm growth $(\beta=0.19, p<0.01)$. However, the effect of perceived corruption on firm growth was not statistically significant $(\beta=0.02, n s)$. Overall, the results of the mediation analysis suggest that institutional networking mediates the effect of perceived corruption on firm growth. Thus, hypothesis 2 is supported.

To gain additional insights into the mediation results, we utilised the Sobel test to investigate the statistical significance of the indirect effects of institutional networking on firm growth (MacKinnon and Dwyer, 1993; Sobel, 1982). Using this test, we calculated the magnitude of the unstandardised indirect effect and its associated standard error. The results of this test indicate that the indirect effects of institutional networking on firm growth $(z=2.98, p<0.01)$ were consistent with our prediction and statistically significant. This provides further support for full mediation (H2).

\subsection{Robustness checks}

The robustness of the results was established by performing several analyses. First, we undertook an alternative regression analysis utilising return on assets (ROA) (Venkatraman and Ramanujam, 1986) as our dependent variable. This measure was computed as the ratio of operating income to total assets (Lee et al., 2016; Florio and Leoni, 2017). The results using ROA replicated our initial regression 
results. Second, we used financial resource availability (Cooper et al., 1994; Wiklund and Shepherd, 2005) as a proxy for financial slack and tested its effect on the relationship between perceived corruption and institutional networking $(\beta=0.33, p<0.01)$. Finally, in the second wave of the survey, we obtained information on bribery incidence from the finance managers and used this measure ('It is common for firms in my line of business to pay some irregular 'additional payments/gifts' to get things done concerning customs, taxes, licences, regulations, and services') as an alternative measure of corruption (Hanousek and Kochanova, 2016). Accordingly, we re-estimated the mediating effect of institutional networking on the relationship between corruption and firm growth. The results were consistent with the findings in Table 2.

Thus, overall, the results obtained from the robustness test were in line with our initial findings. Third, we performed the Durban-Wu-Hausman test to examine potential endogeneity in the model by using instrumental variables (Wooldridge, 2002). The criteria for instrumental variables consisted of those that affect the level of corruption, but which do not affect firm growth (Semadeni et al., 2014). Consistent with the recommendations of Semadeni et al. (2014), we employed multiple instrumental variables. Specifically, weak institutional environment and pressures from family members for financial support met the aforementioned selection criteria and were used as instrumental variables. Accordingly, we regressed each variable separately on perceived corruption. We then saved the residuals and entered them into the model. The $p$-values were not significant for either residual, indicating that the effects of endogeneity are likely minimal in our research model.

\section{Discussion and conclusion}

Drawing on institutional theory and corruption literature, this paper argues that perceived corruption affects firm growth through institutional networking. Accordingly, we put forward a moderated mediation model that examined the relationship between perceived corruption and firm growth. Using data from 212 SMEs in Ghana, the analysis revealed that the relationship between corruption and firm growth is mediated by institutional networking, and this relationship is enhanced at high levels of financial slack. In other words, the study shows that perceived corruption is positively associated with institutional networking, which in turn positively impacts SMEs' growth. Furthermore, the research revealed that the relationship between perceived corruption and institutional networking is stronger for SMEs that possess higher financial slack.

Theoretically, our study makes three main contributions. First, we contribute to the emerging literature examining the effect of corruption on firm performance. Given that the findings from previous studies are mixed, our study sheds additional light on this relationship by testing the effect of perceived corruption on SMEs' firm growth. Thus, our findings complement the small number of studies that have demonstrated the positive relationship between corruption and firm performance (Hanousek, and Kochanova, 2016; Vial and Hanoteau, 2010). Second, our study provides a nuanced understanding of the mechanism, institutional networking, through which corruption positively affects firm performance. In doing so, we open up the 'black box' of the relationship between corruption and firm performance. In the main, our findings provide useful insights into how institutional networking mediates the corruption-firm performance linkage. In this way, our study contributes to extant research efforts exploring the effects of social ties on firm growth/performance in emerging economies (Guo et al., 2014; Lin and Lin, 2016). Third, previous studies have considered institutional networking and financial slack in isolation. Therefore, we extend the literature by simultaneously testing the relationships among these variables in a contingency model. The outcomes show that financial slack amplifies the relationship between perceived corruption and institutional networking. By doing so, we fill an important research void in the entrepreneurship literature regarding the 'value' of financial slack for SMEs in environments where it is challenging to access credit (Wellalage et al., 2019a).

Our study also provides useful insights to SME founders and policy makers in developing countries. First, given the importance of institutional networking in an environment where corruption is prevalent, SMEs would be better served by deploying resources towards developing and nourishing 
institutional networking. Such actions can help to mitigate the uncertainties associated with operating in countries with weak institutional environments and where corruption is very prevalent. The finding regarding the effect of networking suggests that entrepreneurs' relationship with the government and bureaucratic officials can go a long way in helping SMEs gain access to resources and privileges that often are crucial for firm survival and success in such environments. As firms increasingly use institutional ties to access resources, future success is likely to be predicated on their ability to develop and maintain diverse institutional ties. Thus, there is a need to develop and maintain ties across political parties and agencies to mitigate network decay or obsolescence due to changes in government and accompanying administrative changes. Relatedly, the finding concerning the moderating effect of financial slack on the link between perceived corruption and institutional networking implies that SMEs that possess financial slack will likely be in a better position to establish good relationships with diverse institutional ties. This is because it is challenging to attain capital (e.g. loans) in such environments. However, it is important to recognise that, although corruption may allow entrepreneurs to temporarily remove bureaucratic bottlenecks that significantly increase their transaction costs, a culture of unrestricted bribery may encourage opportunistic civil servants to intentionally impose such bottlenecks to enrich themselves. This could increase the cost of doing business and adversely affect economic development. ${ }^{4}$

\section{Limitations and future research directions}

There are some limitations of our study, which can inform the direction for future research. First, this study focuses solely on Ghana. Therefore, researchers should be cautious of generalising our findings to other developing countries, given the variation in the political and socio-economic cultures and practices across developing countries. Consequently, it may be useful for future research to test our model with data from a more diverse and larger sample across national/cultural settings. Second, future studies could determine the direction of the hypothesised relationships in our research model by using a longitudinal method to investigate whether entrepreneurs' perceptions of corruption and institutional network change over time and how such changes influence firm growth. Relatedly, future research could examine how firm performance, over time, influences the perception of corruption and institutional networking. Fourth, recent research has highlighted the contingencies such as gender (Wellalage et al., 2019b), types of entrepreneurships (Goel and Saunoris, 2019), and types of bribes ( $\mathrm{Vu}$ et al., 2018) that can affect the relationship between corruption and firm performance. Future research can incorporate these contingencies into our theoretical model to better understand if and how these factors affect our findings. Furthermore, researchers can also examine the impact of other forms of financial resources (e.g. loans) on the relationship between perceived corruption and institutional networking. Finally, researchers can build on our study by examining a broader set of firm outcomes. For instance, Lee and Weng (2013) find that bribery in the home country can dampen firm exports. This suggests that, although corruption could enhance firms' performance (growth), it may also lower their competitiveness in international markets. We hope that the insights from our study will prompt new research directions on this topic, especially in developing economies.

\section{References}

Ablo, A. D. (2019), 'Actors, Networks and Assemblages: Local Content, Corruption and the Politics of SME's Participation in Ghana's oil and gas Industry', International Development Planning Review, 41(2): 193-214.

Acquaah, M. (2007), 'Managerial Social Capital, Strategic Orientation and Organizational Performance in an Emerging Economy', Strategic Management Journal, 28(12): 1235-1255.

Adomako, S., R. A. Opoku and K. Frimpong (2018), 'Entrepreneurs' Improvisational Behavior and new Venture Performance: Firm-Level and Institutional Contingencies', Journal of Business Research, 83(4): 10-18.

\footnotetext{
${ }^{4}$ We thank one of the reviewers for encouraging us to elaborate on the long-term implications of corruption on entrepreneurial activities in weak institutional environments.
} 
Adomako, S., K. Frimpong, A. Danso, J. Amankwah-Amoah, M. Uddin and K. Kesse (2020), 'Home Country Institutional Impediments and International Expansion of Developing Country SMEs', International Business Review, doi.org/10.1016/j. ibusrev.2020.101716.

Ahsan, M., S. Adomako and K. Mole (2020), 'Perceived Institutional Support and Small Venture Performance: The Mediating Role of Entrepreneurial Persistence', International Small Business Journal. https://doi.org/10.1177/0266242620943194.

Aiken, L. S., S. G. West and R. R. Reno (1991), Multiple Regression: Testing and Interpreting Interactions, Newbury Park, CA: Sage.

Alm, J., J. Martinez-Vazquez and C. McClellan (2016), 'Corruption and Firm Tax Evasion', Journal of Economic Behavior \& Organization, 100(124): 146-163.

Amankwah-Amoah, J. (2016), 'The Evolution of Science, Technology and Innovation Policies: A Review of the Ghanaian Experience', Technological Forecasting and Social Change, 110(C): 134-142.

Ang, S. and D. W. Straub (1998), 'Production and Transaction Economies and IS Outsourcing: A Study of the US Banking Industry', MIS Quarterly, 22(4): 535-552.

Anokhin, S. and W. S. Schulze (2009), 'Entrepreneurship, Innovation, and Corruption', Journal of Business Venturing, 24(5): 465-476.

Armstrong, J. S. and T. Overton (1977), 'Estimating Non-Response Bias in Mail Surveys', Journal of Marketing Research, 14(3): 396-402.

Avnimelech, G. and Y. Zelekha (2015), 'The Impact of Corruption on Entrepreneurship', in T. Wolf, and T. Issa (eds), International Business Ethics and Growth Opportunities, Hershey, PA: IGI Global, pp. 282-294.

Bagozzi, R. P. and Y. Yi (1988), 'On the Evaluation of Structural Equation models', Journal of Academy of Marketing Science, 16(1): 74-94.

Baker, T., E. Gedajlovic and M. Lubatkin (2005), 'A Framework for Comparing Entrepreneurship Processes Across Nations', Journal of International Business Studies, 36(5): 492-504.

Bardhan, P. (1997), 'Corruption and Development: A Review of Issues', Journal of Economic Literature, 35(3): 1320-1346.

Barkemeyer, R., L. Preuss and M. Ohana (2018), 'Developing Country Firms and the Challenge of Corruption: Do Company Commitments Mirror the Quality of National-Level Institutions?', Journal of Business Research, 90(C): 26-39.

Baron, R. M. and D. A. Kenny (1986), 'The Moderator-Mediator variable Distinction in Social Psychological Research: Conceptual, Strategic, and Statistical Considerations', Journal of Personality and Social Psychology, 51(6): 1173-1182.

Barton, A. H. (1985), 'Determinants of Economic Attitudes in the American Business Elite', American Journal of Sociology, 91(1): 54-87.

Baumol, W. J. (1990), 'Entrepreneurship: Productive, Unproductive, and Destructive', Journal of Political Economy, 98(5): 893-921.

Boudreaux, C. J. (2014), 'Jumping off of the Great Gatsby Curve: How Institutions Facilitate Entrepreneurship and Intergenerational Mobility', Journal of Institutional Economics, 10(2): 231-255.

Brouwer, E., A. Kleinknecht and J. O. N. Reijnen (1993), 'Employment Growth and Innovation at the Firm Level', Journal of Evolutionary Economics, 3(2): 153-159.

Brüderl, J. and P. Preisendörfer (1998), 'Network Support and the Success of Newly Founded Business', Small Business Economics, 10(3): 213-225.

Bryant, C. E. and R. G. Javalgi (2016), 'Global Economic Integration in Developing Countries: The Role of Corruption and Human Capital Investment', Journal of Business Ethics, 136(3): 437-450.

Cheng, J. L. and I. F. Kesner (1997), 'Organizational Slack and Response to Environmental Shifts: The Impact of Resource Allocation Patterns', Journal of Management, 23(1): 1-18.

Child, J. and L. H. Hsieh (2014), 'Decision Mode, Information and Network Attachment in the Internationalization of SMEs: A Configurational and Contingency Analysis', Journal of World Business, 49(4): 598-610.

Cohen, J., P. Cohen, S. G. West and L. S. Aiken (2003), Applied Multiple Regression/Correlation Analysis for the Behavioral Sciences (3rd edn), New Jersey: Lawrence Erlbaum.

Collins, J. D., J. S. McMullen and C. R. Reutzel (2016), 'Distributive Justice, Corruption, and Entrepreneurial Behaviour', Small Business Economics, 47(4): 981-1006.

Cooper, A. C., F. J. Gimeno-Gascon and C. Y. Woo (1994), 'Initial Human and Financial Capital as Predictors of new Venture Performance', Journal of Business Venturing, 9(5): 371-395.

D’Aveni, R. A. and I. F. Kesner (1993), 'Top Managerial Prestige, Power and Tender Offer Response: A Study of Elite Social Networks and Target Firm Cooperation During Takeovers', Organization Science, 4(2): 123-151.

Davis, G. F., M. Yoo and W. E. Baker (2003), 'The Small World of the American Corporate Elite, 1982-2001', Strategic Organization, 1(3): 301-326.

Della Porta, D. and A. Vannucci (1999), Corrupt Exchanges: Actors, Resources, and Mechanisms of Political Corruption, New York: Aldine de Gruyter.

De Rosa, D., N. Gooroochurn and H. Görg (2015), 'Corruption and Productivity: Firm-Level Evidence', Jahrbücher für Nationalökonomie und Statistik, 235(2): 115-138. 
Dheer, R. J. (2017), 'Cross-national Differences in Entrepreneurial Activity: Role of Culture and Institutional Factors', Small Business Economics, 48(4): 813-842.

Doh, J. P., P. Rodriguez, K. Uhlenbruck, J. Collins and L. Eden (2003), 'Coping with Corruption in Foreign Markets', Academy of Management Perspectives, 17(3): 114-127.

Dreher, A. and M. Gassebner (2013), 'Greasing the Wheels? The Impact of Regulations and Corruption on Firm Entry', Public Choice, 155(3-4): 413-432.

Dutta, N. and R. Sobel (2016), 'Does Corruption Ever Help Entrepreneurship?', Small Business Economics, 47(1): 179-199.

Engel, Y., M. Kaandorp and T. Elfring (2017), 'Toward a Dynamic Process Model of Entrepreneurial Networking Under Uncertainty', Journal of Business Venturing, 32(1): 35-51.

Fainshmidt, S., W. Q. Judge, R. V. Aguilera and A. Smith (2018), 'Varieties of Institutional Systems: A Contextual Taxonomy of Understudied Countries', Journal of World Business, 53(3): 307-322.

Feng, X., A. C. Johansson and T. Zhang (2015), 'Mixing Business with Politics: Political Participation by Entrepreneurs in China', Journal of Banking \& Finance, 59(10): 220-235.

Fisman, R. and J. Svensson (2007), 'Are Corruption and Taxation Really Harmful to Growth? Firm Level Evidence', Journal of Development Economics, 83(1): 63-75.

Florio, C. and G. Leoni (2017), 'Enterprise Risk Management and Firm Performance: The Italian Case', British Accounting Review, 49(1): 56-74.

Fornell, C. and D. F. Larcker (1981), 'Evaluating Structural Equation Models with Unobservable Variables and Measurement Error', Journal of Marketing Research, 18(1): 39-50.

Ge, J., M. Carney and F. Kellermanns (2019), "Who Fills Institutional Voids? Entrepreneurs' Utilization of Political and Family Ties in Emerging Markets", Entrepreneurship Theory and Practice, 43(6): 1124-1147.

Getz, K. A. and R. J. Volkema (2001), 'Culture, Perceived Corruption, and Economics: A Model of Predictors and Outcomes', Business \& Society, 40(1): 7-30.

Goel, R. K. and J. W. Saunoris (2019), 'International Corruption and its Impacts Across Entrepreneurship Types', Managerial and Decision Economics, 40(5): 475-487.

Gorsira, M., A. Denkers and W. Huisman (2018), 'Both Sides of the Coin: Motives for Corruption among Public Officials and Business Employees', Journal of Business Ethics, 151(1): 179-194.

Greenwood, P. E. and M. S. Nikulin (1996), A Guide to Chi-Squared Testing, New York: Wiley.

Grossman, H. I. and M. Kim (1995), 'Swords or Ploughshares? A Theory of the Security of Claims to Property', Journal of Political Economy, 103(6): 1275-1289.

Gründler, K. and N. Potrafke (2019), 'Corruption and Economic Growth: New Empirical Evidence', European Journal of Political Economy, 60(C): 101810.

Guo, H., E. Xu and M. Jacobs (2014), 'Managerial Political Ties and Firm Performance During Institutional Transitions: An Analysis of Mediating mechanisms', Journal of Business Research, 67(2): 116-127.

Guseva, A. (2007), 'Friends and Foes: Informal Networks in the Soviet Union', East European Quarterly, 41(3): $323-347$.

Hallen, B. L. and K. M. Eisenhardt (2012), 'Catalyzing Strategies and Efficient tie Formation: How Entrepreneurial Firms Obtain Investment Ties', Academy of Management Journal, 55(1): 35-70.

Hanousek, J. and A. Kochanova (2016), 'Bribery Environments and Firm Performance: Evidence from CEE Countries', European Journal of Political Economy, 43(C): 14-28.

Henrekson, M. and T. Sanandaji (2011), 'The Interaction of Entrepreneurship and Institutions', Journal of Institutional Economics, 7(1): 47-75.

Hoang, H. and B. Antoncic (2003), 'Network-based Research in Entrepreneurship: A Critical Review', Journal of business venturing, 18(2): 165-187.

Hoang, H. and A. Yi (2015), 'Network-based Research in Entrepreneurship: A Decade in Review', Foundations and Trends in Entrepreneurship, 11(1): 1-54.

Hunt, R. A. (2015), 'Contagion Entrepreneurship: Institutional Support, Strategic Incoherence, and the Social Costs of Over-Entry', Journal of Small Business Management, 53(sup1): 5-29.

Jimenez, A., J. C. Puche-Regaliza, J. A. Jiménez-Eguizábal and I. Alon (2017), 'Political Discretion and Corruption: The Impact of Institutional Quality on Formal and Informal Entrepreneurship', European Journal of International Management, 11(3): 280-300.

Joseph, A. O. (2019), Public Officials' Defense of Bribery as a Culturally Acceptable Behavior in Ghana. Unpublished doctoral dissertation.

Khanna, T. and K. Palepu (1997), 'Why Focused Strategies may be Wrong for Emerging Markets', Harvard Business Review, 75(4): 41-51.

Kim, Y. and S. S. Lui (2015), 'The Impacts of External Network and Business Group on Innovation: Do the Types of Innovation Matter?', Journal of Business Research, 68(9): 1964-1973.

Kiss, A. N., S. Fernhaber and P. P. McDougall-Covin (2018), 'Slack, Innovation, and Export Intensity: Implications for Smalland Medium-Sized Enterprises', Entrepreneurship Theory and Practice, 42(5): 671-697. 
Kraatz, M. S. and E. J. Zajac (2001), 'How Organizational Resources Affect Strategic Change and Performance in Turbulent Environments: Theory and Evidence', Organization Science, 12(5): 632-657.

Lambsdorff, J. G., M. Taube and M. Schramm (2004), The new institutional economics of corruption. Routledge, London.

Lee, S. H. and D. H. Weng (2013), 'Does Bribery in the Home Country Promote or Dampen Firm Exports?', Strategic Management Journal, 34(12): 1472-1487.

Lee, K. H., B. C. Cin and E. Y. Lee (2016), 'Environmental Responsibility and Firm Performance: The Application of an Environmental, Social and Governance Model', Business Strategy and the Environment, 25(1): 40-53.

Lee, K. S., G. H. Lim and S. J. Tan (1999), 'Dealing with Resource Disadvantage: Generic Strategies for SMEs', Small Business Economics, 12(4): 299-311.

Lepak, D. P., K. G. Smith and M. S. Taylor (2007), 'Value Creation and Value Capture: A Multilevel perspective', Academy of Management Review, 32(1): 180-194.

Lin, F. J. and Y. H. Lin (2016), 'The Effect of Network Relationship on the Performance of SMEs', Journal of Business Research, 69(5): 1780-1784.

Lindell, M. K. and D. J. Whitney (2001), 'Accounting for Common Method Variance in Cross-Sectional Research Designs', Journal of Applied Psychology, 86(1): 114-121.

Ling, Y., Z. Simsek, M. H. Lubatkin and J. F. Veiga (2008), 'The Impact of Transformational CEOs on the Performance of Small-to Medium-Sized Firms: Does Organizational Context Matter?', Journal of Applied Psychology, 93(4): 923-934.

Luiz, J. M. and C. Stewart (2014), 'Corruption, South African Multinational Enterprises and Institutions in Africa', Journal of Business Ethics, 124(3): 383-398.

Luo, Y. (2005), 'Transactional Characteristics, Institutional Environment and Joint Venture Contracts', Journal of International Business Studies, 36(2): 209-230.

Luo, X., M. K. Hsu and S. S. Liu (2008), 'The Moderating Role of Institutional Networking in the Customer OrientationTrust/Commitment-Performance Causal Chain in China', Journal of the Academy of Marketing Science, 36(2): 202-214.

MacKinnon, D. P. and J. H. Dwyer (1993), 'Estimating Mediated Effects in Prevention Studies', Evaluation Review, 17(2): 144-158.

MacKinnon, D., K. Chapman and A. Cumbers (2004), 'Networking, Trust and Embeddedness amongst SMEs in the Aberdeen Oil Complex', Entrepreneurship \& Regional Development, 16(2): 87-106.

Maclean, M., C. Harvey and R. Chia (2010), 'Dominant Corporate Agents and the Power Elite in France and Britain', Organization Studies, 31(3): 327-348.

Maclean, M., C. Harvey and G. Kling (2017), 'Elite Business Networks and the Field of Power: A Matter of Class?', Theory, Culture \& Society, 34(5-6): 127-151.

Magnani, G. and A. Zucchella (2019), 'Coping with Uncertainty in the Internationalisation Strategy', International Marketing Review, 36(1): 131-163.

McMullen, J. S. and D. A. Shepherd (2006), 'Entrepreneurial Action and the Role of Uncertainty in the Theory of the Entrepreneur', Academy of Management Review, 31(1): 132-152.

Mo, P. H. (2001), 'Corruption and Economic Growth', Journal of Comparative Economics, 29(1): 66-79.

Mohamadi, A., J. Peltonen and J. Wincent (2017), 'Government Efficiency and Corruption: A Country-Level Study with Implications for Entrepreneurship', Journal of Business Venturing Insights, 8(C): 50-55.

Moo, F. and A. Eyiah (2019), 'Factors Influencing the Growth of Small and Medium Construction Firms in Northern Ghana', Journal of African Business, 21(3): 416-431.

Murphy, K. M., A. Shleifer and R. W. Vishny (1991), 'The Allocation of Talent: Implications for Growth', Quarterly Journal of Economics, 106(2): 503-530.

Neter, J., W. Wasserman and M. H. Kutner (1990), Applied Linear Statistical Models (3rd edn), Homewood, IL: Irwin.

Olken, B. A. and R. Pande (2012), 'Corruption in Developing Countries', Annual Review of Economics, 4(1): 479-509.

Phillips, N., P. Tracey and N. Karra (2013), 'Building Entrepreneurial tie Portfolios Through Strategic Homophily: The Role of Narrative Identity Work in Venture Creation and Early Growth', Journal of Business Venturing, 28(1): 134-150.

Podsakoff, P. M., S. B. MacKenzie, L. Jeong-Yeon and N. P. Podsakoff (2003), 'Common Method Biases in Behavioral Research: A Critical Review of the Literature and Recommended Remedies', Journal of Applied Psychology, 88(5): 879-903.

Puffer, S. M., D. J. McCarthy and M. Boisot (2010), 'Entrepreneurship in Russia and China: The Impact of Formal Institutional Voids', Entrepreneurship Theory and Practice, 34(3): 441-467.

Robson, P. J. and B. A. Obeng (2008), 'The Barriers to Growth in Ghana', Small Business Economics, 30(4): $385-403$.

Rogelberg, S. and J. Stanton (2007), 'Understanding and Dealing with Organisational Survey Nonresponse', Organisational Research Methods, 10(2): 195-209.

Rose-Ackerman, S. (1999), Corruption and Government. Causes, Consequences, and Reform, Cambridge: Cambridge University Press.

Rose-Ackerman, S. (2001), 'Trust and Honesty in Post-Socialist Societies', Kyklos, 54(3): 415-444.

Sawyerr, O. O., J. McGee and M. Peterson (2003), 'Perceived Uncertainty and Firm Performance in SMEs: The Role of Personal Networking Activities', International Small Business Journal, 21(3): 269-290. 
Semadeni, M., M. C. Withers and S. Trevis Certo (2014), 'The Perils of Endogeneity and Instrumental Variables in Strategy Research: Understanding Through Simulations', Strategic Management Journal, 35(7): 1070-1079.

Semrau, T. and S. Sigmund (2012), 'Networking Ability and the Financial Performance of New Ventures: A Mediation Analysis among Younger and More Mature Firms', Strategic Entrepreneurship Journal, 6(4): 335-354.

Shleifer, A. and R. W. Vishny (1993), 'Corruption', The Quarterly Journal of Economics, 108(3): 599-617.

Sobel, M. E. (1982), 'Asymptotic Confidence Intervals for Indirect Effects in Structural Equations Models', in S. Leinhart (ed.), Sociological Methodology, San Francisco: Jossey-Bass, pp. 290-312.

Sun, P., K. Mellahi and M. Wright (2012), 'The Contingent Value of Corporate Political Ties', Academy of Management Perspectives, 26(3): 68-82.

Svensson, J. (2005), 'Eight Questions about Corruption', Journal of Economic Perspectives, 19(3): 19-42.

Tanzi, V. (1998), 'Corruption Around the World: Causes, Consequences, Scope, and Cures', Staff Papers, 45(4): 559-594.

Terziovski, M. (2010), 'Innovation Practice and its Performance Implications in Small and Medium Enterprises (SMEs) in the Manufacturing Sector: A Resource-Based View', Strategic Management Journal, 31(8): 892-902.

Tonoyan, V., R. Strohmeyer, M. Habib and M. Perlitz (2010), 'Corruption and Entrepreneurship: How Formal and Informal Institutions Shape Small Firm Behavior in Transition and Mature Market Economies', Entrepreneurship Theory and Practice, 34(5): 803-832.

Transparency International (2017), Corruption Perception Index, Berlin. Available at https://www.transparency.org/country/ GHA (accessed 2 July 2019).

Uhlenbruck, K., P. Rodriguez, J. Doh and L. Eden (2006), 'The Impact of Corruption on Entry Strategy: Evidence from Telecommunication Projects in Emerging Economies', Organization Science, 17(3): 402-414.

Venkatraman, N. and V. Ramanujam (1986), 'Measurement of Business Performance in Strategy Research: A Comparison of Approaches', Academy of Management Review, 11(4): 801-814.

Vial, V. and J. Hanoteau (2010), 'Corruption, Manufacturing Plant Growth, and the Asian Paradox: Indonesian Evidence', World Development, 38(5): 693-705.

Vorley, T. and N. Williams (2016), "Between Petty Corruption and Criminal Extortion: How Entrepreneurs in Bulgaria and Romania Operate within A Devil's Circle”, International Small Business Journal, 34(6): 797-817.

Voss, G. B., D. Sirdeshmukh and Z. G. Voss (2008), 'The Effects of Slack Resources and Environmental Threat on Product Exploration and Exploitation', Academy of Management Journal, 51(1): 147-164.

Vu, H. V., T. Q. Tran, T. Van Nguyen and S. Lim (2018), 'Corruption, Types of Corruption and Firm Financial Performance: New Evidence from A Transitional Economy', Journal of Business Ethics, 148(4): 847-858.

Wang, F., L. Xu, J. Zhang and W. Shu (2018), 'Political Connections, Internal Control and Firm Value: Evidence from China's Anti-Corruption Campaign', Journal of Business Research, 86: 53-67.

Wellalage, N. H., S. Locke and H. Samujh (2019a), 'Firm Bribery and Credit Access: Evidence from Indian SMEs', Small Business Economics, 55(3): 283-304.

Wellalage, N. H., S. Locke and H. Samujh (2019b), 'Corruption, Gender and Credit Constraints: Evidence From South Asian SMEs', Journal of Business Ethics, 159(1): 267-280.

Wiklund, J. and D. Shepherd (2005), 'Entrepreneurial Orientation and Small Business Performance: A Configurational Approach', Journal of Business Venturing, 20(1): 71-91.

Wooldridge, J. M. (2002), Econometric Analysis of Cross Section and Panel Data, Cambridge, MA: MIT Press.

Zhang, X., X. Ma, Y. Wang, X. Li and D. Huo (2016), 'What Drives the Internationalization of Chinese SMEs? The Joint Effects of International Entrepreneurship Characteristics, Network Ties, and Firm Ownership', International Business Review, 25(2): 522-534.

Zhao, X., J. G. Lynch Jr and Q. Chen (2010), 'Reconsidering Baron and Kenny: Myths and Truths About Mediation Analysis', Journal of Consumer Research, 37(2): 197-206.

Zheng, C., M. Ahsan and A. F. DeNoble (2020), 'Entrepreneurial Networking During Early Stages of Opportunity Exploitation: Agency of Novice and Experienced new Venture Leaders', Entrepreneurship Theory and Practice, 44(4): 671-699.

Zhou, W. (2013), 'Political Connections and Entrepreneurial Investment: Evidence from China's Transition Economy', Journal of Business Venturing, 28(2): 299-315.

\section{Appendix 1: Survey items}

Perceived corruption (0.93)

- In this industry, irregular, additional payments to various government officials are required to 'get things done'.

- Businesses generally must engage in various types of corruption in order to compete effectively in this industry.

- Engaging in various types of corruptions is a normal part of doing business in this industry.

- Firms which do not engage in corruption will be at a competitive disadvantage compared to firms that do engage in these types of actions. 
- Corruption is one of the most important considerations when doing business in this industry.

- Engaging in corruption is the way things get done in this industry.

Institutional networking $(\alpha=0.88)$

- Top managers at our firm have maintained good personal relationships with officials in various levels of government.

- So far, our firm's relationship with regional government officials has been in a good shape.

- Top managers at our firm have developed good connections with officials in regulatory and supporting organisations such as tax bureaus, state banks and commercial administration bureaus.

- Top managers at our firm have maintained good relationships with officials in industrial and investment institutions (e.g. Investment Board, Export Promotion Council, Ghana Stock Exchange).

Cite this article: Adomako S, Ahsan M, Amankwah-Amoah J, Danso A, Kesse K, Frimpong K (2021). Corruption and SME growth: the roles of institutional networking and financial slack. Journal of Institutional Economics 17, 607-624. https:// doi.org/10.1017/S1744137421000011 